\title{
Design approach for the optimal model of an energy-efficient timber building with various glazing types and surfaces on the south façade
}

\author{
V. Žegarac Leskovar \& M. Premrov \\ Faculty of Civil Engineering, University of Maribor, Slovenia
}

\begin{abstract}
The paper presents the reasonability of using an increased proportion of glazing surfaces in prefabricated timber buildings with a special focus on energy efficiency by using an enlarged glazing area on the south façade of the object. The research is based on a case study of a two-storey house built in a prefabricated timber-frame structural system taking the climate data for Ljubljana into consideration. Parametric analysis is performed on a variation of an increased proportion of the glazed surfaces' impact on the south side of the building according to the total surface of the south façade (AGAW) as a basic variable. The analysis was carried out on different exterior wall elements having different thermal properties, while the rest of the parameters, such as the ground plan of the model as well as the active systems, roof and floor slab assemblies, climate condition, etc. remain constant. The impact of different types of glazing with various $\mathrm{U}_{\text {glass }}$-values is additionally studied. The basic practical contribution of the study is that the results presenting the determined function for the optimal south oriented glazing size $\left(\mathrm{AGAW}_{\text {opt }}\right)$ offer us the opportunity of selecting the optimal way of energy-efficient renovation of existing timber-frame housing with a possible combination of improving the thermal properties of the external walls with the installation of an additional insulation layer (decreasing U-wall value) and of the optimal of glazing area size on the south-oriented façade, which is, in the case of a lower $\mathrm{U}_{\text {wall-value, noticeably lower. }}$
\end{abstract}

Keywords: timber structures, energy efficiency, glazing, renovation. 


\section{Introduction}

The present times, characterized by specific circumstances in the sphere of climate change, witness an intensive focus of the sciences of civil engineering and architecture on searching for ecological solutions and construction methods that would allow for greater energy efficiency and, consequently, for a reduced environmental burden. Being a natural raw material, timber represents one of the best choices for energy efficient construction since it also functions as a good thermal insulator, has good mechanical properties and ensures a comfortable indoor living climate. Therefore, there is an increasing tendency worldwide toward building multi-level prefabricated timber structures. Nevertheless, it was clear to competitive fields of building that today's timber frame building is extremely high valued and is capable of fulfilling all the demands from society and the environment we live in. There are many arguments for timber-frame residential buildings; let us count the most important: very good building physical properties, built-in materials show environmental excellence, lower energy consumption, the speed of build and good seismic security.

The main bearing capacity vertical elements in the timber-framed buildings are prefabricated timber-framed walls. The wall is a composite element consisting of framed panels made from sheets of board-material fixed by mechanical fasteners to one or both sides of the timber frame (Figure 1). There are many types of panel products available which may have some structural capacity such as wood-based materials (plywood, oriented strand board, hardboard, particleboard, etc.) or plaster boards and, more recently, fibre-plaster boards.

The features listed above make prefabricated timber structures suitable for the construction of energy efficient houses of various standards where an increased proportion and a suitable orientation of the glazing surfaces play an important part due to solar heat gains. Over a number of years of development, glazing

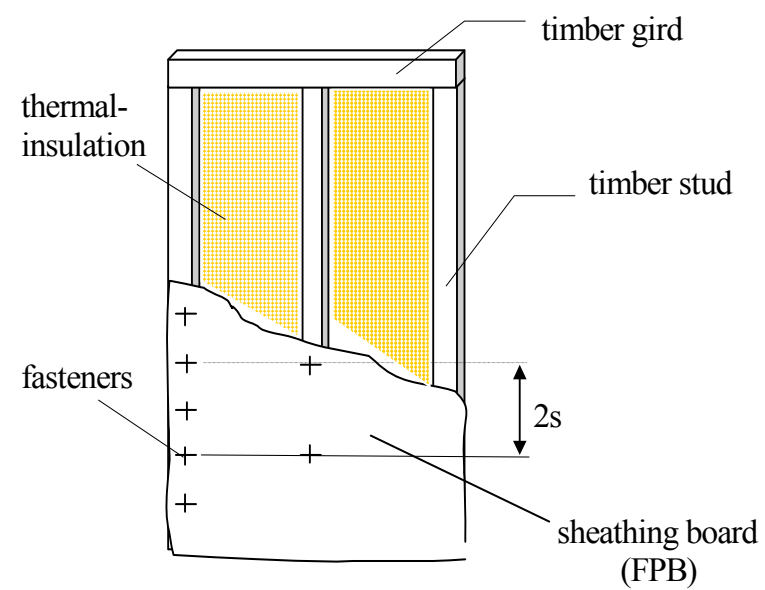

Figure 1: Composition of the timber-framed wall element. 
manufacturers have improved their products' thermal-insulation and strength properties as well as their coefficient of permeability of total solar radiation energy and thus enabled the use of large glazing surfaces, primarily southoriented, not only to illuminate indoor areas but also to ensure solar heating (Johnson et al., [1], Inanici and Demirbilek [2], Bülow-Hübe [3], Persson et al. [4], Bouden [5], Ford et al. [6]). It follows that timber construction along with the use of suitable and correctly oriented glazing surfaces represents a great potential in residential and public building construction. And this paper mainly deals with this problem. How to improve the energy efficiency of prefabricated timber buildings by using optimal size, orientation and type of glazing?

\section{Basic requirements of energy efficient timber house design}

The definition of an energy efficient architectural design is related to the specific design approach comprising exactly defined parameters which influence the energy balance of buildings. The basis of energy-efficient house design is to take advantage of as many renewable energy sources and of climatic conditions in combination with low energy technology as possible in order to reduce the need for conventional building technology which is inefficient or consumes a lot of fossil fuel energy. Parallel to a reduced demand for a fossil fuel to heat the building, the $\mathrm{CO}_{2}$ emissions are reduced as well. Therefore, commonly used terms, such as climate-conscious architecture, bio-climatic architecture or energy-efficient architecture, present specific approaches in contemporary architectural building design, which have to be applied in conjunction with the structural and aesthetic aspects of architecture.

There exist few classifications of energy-efficient houses that differ from each other minimally regarding energy demand. As an example, a low-energy house is a house with an annual requirement for a space heating energy demand of less than $50 \mathrm{kWh} / \mathrm{m}^{2} \mathrm{a}$, however the requirements differ from one country to another, while for a passive house this requirement is strictly defined with the value being lower than $15 \mathrm{kWh} / \mathrm{m}^{2} \mathrm{a}$ in all countries. Besides the space heating energy demand, additional parameters, such as the U-value of external building elements, the air tightness of the building's envelope, window quality, building form etc., have to meet specific demands.

In an energy-efficient house, the specified low energy consumption can be achieved by a well-considered design that includes a proper selection of building materials, excellent envelope insulation, air tightness, thermally efficient glazing, a compact form of the building, construction without thermal bridges and passive solar design which is preconditioned by appropriate southern orientation with well-designed shading. On the other hand, active house design systems include heat recovery ventilation, ground source heat pumps, lighting with low energy lamps and more (Figure 2).

In passive houses a comfortable living environment is achieved without using conventional heating and cooling systems. The basis of passive house design is to take advantage of passive technologies as much as possible in order to reduce the need for the energy provided by fossil fuel. The passive design technologies 


\section{COOLING}

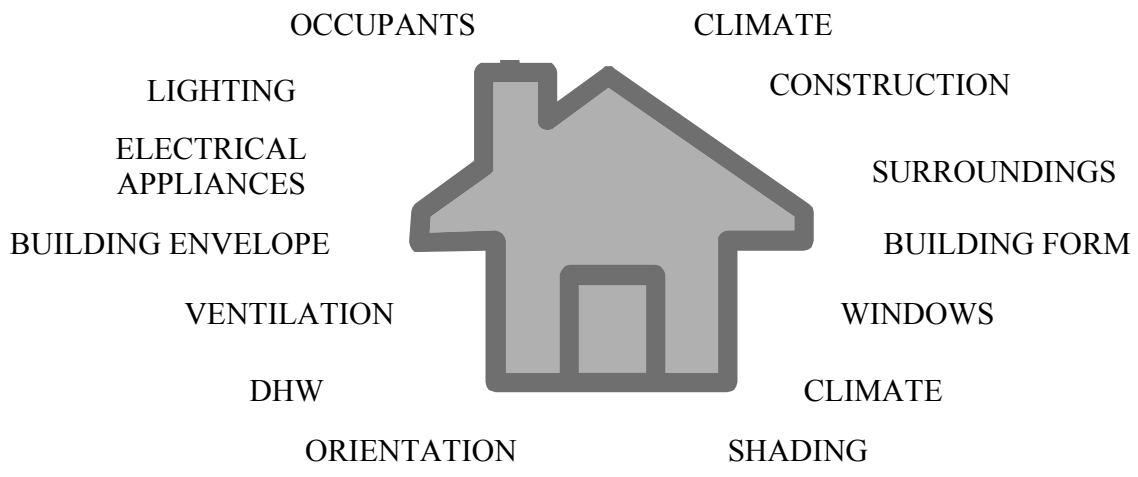

HEATING SYSTEM

Figure 2: Different parameters that influence the design of an energyefficient house (according to Persson [7]).

and systems include excellent envelope insulation, air tightness, triple glazing and construction without thermal bridges and passive solar design which is preconditioned by appropriate southern orientation with well designed shading. On the other hand, active house design systems include heat recovery ventilation, ground source heat pumps, lightning with low energy lamps and more.

The Ministry of the Environment and Spatial Planning of the Republic of Slovenia (MOP) is responsible for the transfer of the EBPD into Slovenian legislation. Due to its complexity the transfer was accomplished through three legal acts which are the Construction Act (ZGO-1), the Energy Act (EZ) and the Environmental Protection Act (ZVO-1) and additionally through legal rules, especially through Rules on the efficient use of energy in buildings (PURES 2009 [8]). According to the updated EPBD 2010 requirements, the update of the Rules on the efficient use of energy in buildings is to be adopted in 2010 [9]. According to the explanation in Śijanec Zavrl et al. [10], PURES 2010 [9] prescribes the planning of a building considering the principles of bio-climatic design, which reduces the energy demand for heating and cooling, as well as the total final energy demand. By the end of 2014, the annual energy demand for the heating of new buildings has to be in a range between $30-50 \mathrm{kWh} / \mathrm{m}^{2} \mathrm{a}$, while from 2015 this range will be between $20-40 \mathrm{kWh} / \mathrm{m}^{2} \mathrm{a}$, which. The cooling demand for new buildings is limited as well to a maximum of $50 \mathrm{kWh} / \mathrm{m}^{2} \mathrm{a}$. The maximal total energy demand for operating of all systems has to range between 170 and $200 \mathrm{kWh} / \mathrm{m}^{2}$ a. It is essential to use renewable energy sources to ensure a minimum end-energy use of $25 \%$. There are also many technical obligations which have to be implemented, such as limiting U-values for external construction elements $\left(\mathrm{U}_{\text {wall,max }}=0.28 \mathrm{~W} / \mathrm{m}^{2} \mathrm{~K}\right)$. The three-pane glazing is not prescribed, although it will be necessary to achieve a class A or B rating regarding the Classification of energy-efficient houses (see Table 1). Other requirements are related to the specific performance of ventilation, hot water 
generation and lighting. According to the Slovene legislative framework, particularly to the Energy Act, the system of energy performance certification is defined in Rules on the methodology of construction and issuance of building energy certificates. On the basis of these rules, the classification of energyefficient houses was carried, which is listed in Table 1. For the certification of the buildings two methods are defined. As a first option a calculation procedure is suggested for the determination of energy use parameters, which is based on the EN ISO 13790 standard. And secondly, it is expected to use the method of measuring actual average energy use over a three year period, based on EN 15206.

It is evident from the table that the A1 class can be achieved only by using improved U-value of windows and doors. It follows that suitable and correctly oriented glazing surfaces with highly improved mechanical properties represent a

Table 1: Classification of energy-efficient houses on the basis of "rules on the methodology of construction and issuance of building energy certificates" [9].

\begin{tabular}{|c|c|c|c|}
\hline $\begin{array}{l}\text { Degree / } \\
\text { Classification } \\
\text { in accordance } \\
\text { with the rules }\end{array}$ & $\begin{array}{l}\text { Generally used } \\
\text { classification in } \\
\text { practice }\end{array}$ & $\mathrm{Q}_{\mathrm{h}}{ }^{*}\left[\mathrm{kWh} / \mathrm{m}^{2} \mathrm{a}\right]$ & $\begin{array}{l}\text { Variation of execution } \\
\text { (according to [11] }\end{array}$ \\
\hline Class C & $\begin{array}{l}\text { minimal } \\
\text { requirements for } \\
\text { low-energy house }\end{array}$ & $\begin{array}{l}35-50 \\
(60)\end{array}$ & $\begin{array}{c}\text { classical prefabricated } \\
\text { construction, conventional } \\
\text { heating system, } \\
\text { contemporary windows } \\
\text { (doors), no central } \\
\text { ventilation system } \\
\end{array}$ \\
\hline Class B2 & low-energy house & $25-35$ & $\begin{array}{l}\text { thermally improved } \\
\text { building envelope }\end{array}$ \\
\hline Class B1 & $\begin{array}{c}\text { better low-energy } \\
\text { house }\end{array}$ & $15-25$ & $\begin{array}{c}\text { thermally improved } \\
\text { building envelope }+ \\
\text { HRV }^{* *}+\mathrm{HP}^{* * *}\end{array}$ \\
\hline Class A2 & passive house & $10-15$ & $\begin{array}{l}\text { additionally thermally } \\
\text { improved building } \\
\text { envelope }+\mathrm{HRV}+\mathrm{HP}\end{array}$ \\
\hline Class A1 & 1-litre house & $\leq 10$ & $\begin{array}{l}\text { additionally thermally } \\
\text { improved building } \\
\text { envelope }+\mathrm{HRV}+\mathrm{HP}+ \\
\text { improved U-value of } \\
\text { windows (doors) }\end{array}$ \\
\hline
\end{tabular}

*Specific annual heating demand, **Heat recovery ventilation, ***Heat pump. 
great potential in residential and public building construction and can significantly improve the energy demand in a building. This influence is numerically analysed on a chosen parametric study in Chapter 3.

\section{Parametric analysis of glazing influence}

\subsection{Input data}

\subsubsection{Simulation model}

A model of the two-storey single-family house was designed using a low-energy standard. The external horizontal dimensions are $11.66 \times 8.54 \mathrm{~m}$ for the ground floor and $11.66 \times 9,79 \mathrm{~m}$ for the upper floor. The total heated floor area is $168 \mathrm{~m}^{2}$, Figure 3.
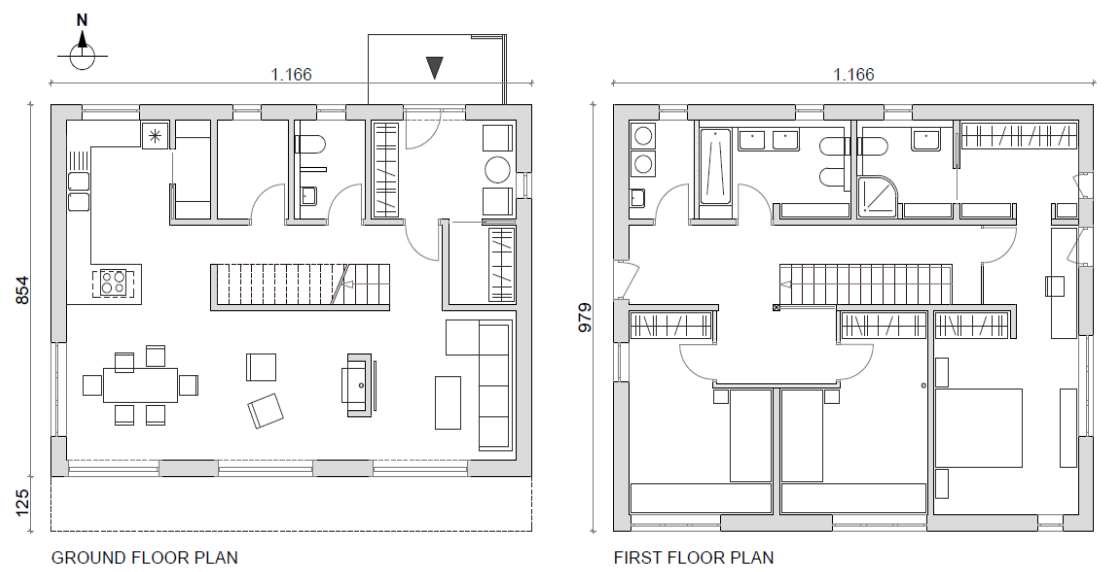

Figure 3: $\quad$ Ground plan of base-case study model.

\subsubsection{Construction}

The exterior walls are constructed using a timber-frame macro-panel system. Owing to the characteristics of the exterior wall the base case model was labelled as TF 2 (see Table 2) with the timber class C22 according to EN 338 [12]. The $\mathrm{U}$-values of the other external construction elements are $0.135 \mathrm{~W} / \mathrm{m}^{2} \mathrm{~K}$ for the floor slab, $0.135 \mathrm{~W} / \mathrm{m}^{2} \mathrm{~K}$ for the flat roof and $0.130 \mathrm{~W} / \mathrm{m}^{2} \mathrm{~K}$ for the southoriented overhang construction above the ground floor area. The composition of a basic TF 2 wall element and of other analysed external wall elements is listed in Table 2.

\subsubsection{Glazing}

A window glazing (Unitop $0.51-52$ - UNIGLAS) with three layers of glass, two low emissive coatings and krypton in the cavities for a normal configuration of 4E-12-4-12-E4, each cavity $12 \mathrm{~mm}$ thick, with $4 \mathrm{~mm}$ thick glass panes, was installed. The glazing configuration with a g-value of $52 \%$ and a $U$-value $\left(U_{g}\right)$ of $0.51 \mathrm{~W} / \mathrm{m}^{2} \mathrm{~K}$ assures a high level of heat insulation and light transmission 
Table 2: Composition of basic TF 2 and of additional analysed timber-frame macro-panel wall elements TF 1 (classic standard) and TF 3 (passive standard).

\begin{tabular}{|c|c|c|c|c|c|}
\hline \multicolumn{2}{|l|}{ TF 1} & \multicolumn{2}{|l|}{ TF 2} & \multicolumn{2}{|l|}{ TF 3} \\
\hline material & $\mathrm{d}[\mathrm{mm}]$ & material & $\mathrm{d}[\mathrm{mm}]$ & material & $\mathrm{d}[\mathrm{mm}]$ \\
\hline rough coating & 6 & rough coating & 6 & rough coating & 9 \\
\hline EPS foam ${ }^{*}$ & 100 & $\mathrm{MW}^{* *}$ & 100 & wood fibreboard & 60 \\
\hline gypsum & 15 & gypsum fibreboard & 15 & 1 & \\
\hline $\begin{array}{l}\text { MW between } \\
\text { timber frame }\end{array}$ & 160 & $\begin{array}{l}\text { MW between } \\
\text { timber frame }\end{array}$ & 160 & $\begin{array}{l}\mathrm{CF}^{* * *} \text { between } \\
\text { timber frame }\end{array}$ & 360 \\
\hline vapour barrier & 0.2 & vapour retarder & 0.2 & $\mathrm{OSB}^{* * *}$ & 15 \\
\hline 7 & l & \begin{tabular}{|ll} 
MW & between \\
$\mathrm{TSS}^{* * * * *}$ & \\
\end{tabular} & 60 & 1 & l \\
\hline gypsum & 15 & gypsum fibreboard & 15 & 1 & 1 \\
\hline gypsum & 10 & gypsum fibreboard & 10 & gypsum & 12.5 \\
\hline $\begin{array}{l}\text { total } \\
{[\mathrm{mm}]}\end{array}$ & 306.2 & $\begin{array}{ll}\text { total } & \text { thickness } \\
{[\mathrm{mm}]} & \\
\end{array}$ & 366.2 & $\begin{array}{ll}\text { total } & \text { thickness } \\
{[\mathrm{mm}]} & \\
\end{array}$ & 456.5 \\
\hline $\begin{array}{l}\mathrm{U}_{\text {wall }}-\text { value } \\
{\left[\mathrm{W} / \mathrm{m}^{2} \mathrm{~K}\right]}\end{array}$ & 0.164 & $\begin{array}{l}\mathrm{U}_{\text {wall }}-\text { value } \\
{\left[\mathrm{W} / \mathrm{m}^{2} \mathrm{~K}\right]}\end{array}$ & 0.137 & $\begin{array}{l}\mathrm{U}_{\text {wall }}-\text { value } \\
{\left[\mathrm{W} / \mathrm{m}^{2} \mathrm{~K}\right]}\end{array}$ & 0.102 \\
\hline
\end{tabular}

Expanded polystyrene foam, ${ }^{* *}$ Mineral wool, ${ }^{* * *}$ Cellulose fibre, ${ }^{* * * *}$ Oriented strand board, ${ }^{* * * * *}$ Timber sub-structure.

(Gustavsen et al. [13]). The window frame U-value $\left(\mathrm{U}_{\mathrm{f}}\right)$ is $0.73 \mathrm{~W} / \mathrm{m}^{2} \mathrm{~K}$, while the frame width is $0.114 \mathrm{~m}$. The glazing to wall area ratio (AGAW) of the south oriented façade is $27.6 \%$, while the AGAW values of the rest of the cardinal directions are $8.9 \%$ on the north, $10.5 \%$ on the east and $8.5 \%$ on the west façades.

\subsubsection{Climate and orientation}

The house is located in Ljubljana and oriented with the longer side with the large glazed area facing south. The city of Ljubljana is located at an altitude of 298 meters, latitude of $46.03^{\circ}$ and longitude of $14.3^{\circ}$ east. According to data from [14] the considered annual external temperature is $9.8^{0} \mathrm{C}$. The average duration of solar radiation is 1712 hours annually.

\subsubsection{Shading}

The house is constructed with a south-oriented extended overhang above the ground floor, which blocks the direct solar radiation from entering the ground floor windows to the south during the summer, while it lets it enter in winter when the angle of incidence of the sun is lower. The rest of the windows on the upper floor and those of the east, west and north-oriented walls are shaded with external shading devices. To avoid results that would not be objective, we decided to shade the north facing glazing areas as well.

\subsubsection{Internal gains and HVAC}

The length of the heating period is 205 days. A value of $2.1 \mathrm{~W} / \mathrm{m}^{2}$ for internal heat gains from electric appliances and body heat was used in the PHPP (internal 
heat sources) calculation. To prevent overheating in the summer period the summer operation of the heat recovery ventilation with an air change rate of $0.30 \mathrm{~h}^{-1}$ was planned. Additional summer ventilation for cooling through manual window night ventilation with an air change rate of $0.15 \mathrm{~h}^{-1}$ was planned as well. The interior temperatures were designed to a $\mathrm{T}_{\min }$ of $20^{\circ} \mathrm{C}$ and a $\mathrm{T}_{\max }$ of $25^{\circ} \mathrm{C}$. No solar collectors were installed.

\subsubsection{Parameters varied}

The influence on energy demand of the following factors was studied: glazing size in four different cardinal directions; south, north, east and west. Modifications were made separately for each cardinal direction for six timber systems; TF1, TF2, TF3 and only for south-oriented glazing areas for three additional systems (TFcl4, TFcl5 and TFcl6) with higher $U$-values $(U=0.70$ $\mathrm{W} / \mathrm{m}^{2} \mathrm{~K}, \mathrm{U}=0.45 \mathrm{~W} / \mathrm{m}^{2} \mathrm{~K}$ and $\mathrm{U}=0.30 \mathrm{~W} / \mathrm{m}^{2} \mathrm{~K}$ ) which are typical for older timber systems built with single-panel wall elements. The modifications of the size of glazing areas were in the range of AGAW (glazing to wall area ratio) of $0 \%$ to nearly $80 \%$, Figure 4 .

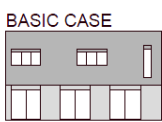

AGAW $=0,33$

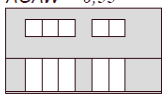

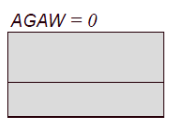

$A G A W=0,39$

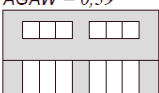

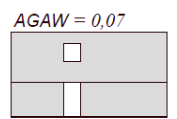

AGAW $=0,46$

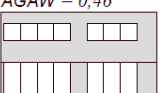

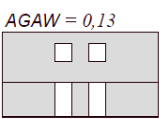

AGAW $=0,52$

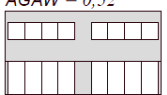

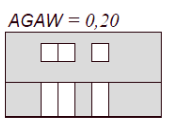

AGAW $=0,59$

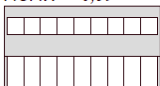

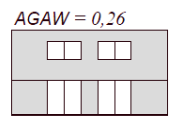

$A G A W=0,79$

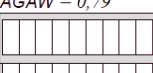

Figure 4: South-oriented façade of the base-case model with schemes of the glazing area size modification.

\subsubsection{Object of the research}

As already presented previously the object of the research was the definition of the most favorable glazing to wall area ratio for each cardinal direction of the house. The results observed in the PHPP calculations were heating demand and cooling demand values.

\subsubsection{Description of the software and calculation method}

The Passive House Planning Package 2007 (PHPP 2007) [15] was used to perform calculations of energy demand. The software is certified as a planning tool for passive houses, although it can be used also for low-energy house design. It is important to stress that the main point of our analyses is to present the approach for the optimal design, therefore the selection of the software is not decisive; many other calculation tools could have been used as well.

\subsection{Results and discussion}

The behaviour of the TF 1, TF2 and TF3 systems for north, west and east direction is very similar because no $\mathrm{Q}_{\mathrm{h}}$ gains are appearing for this orientations (Žegarac Leskovar and Premrov [16]), therefore only the south direction, which 
is the main point of our special interest, will be additionally analysed and compared for all construction systems. The results in Figure 5 are presented separately for energy demand for heating $\mathrm{Q}_{\mathrm{h}}$ (Figure 5a) and total annual energy demand for heating and cooling $\mathrm{Q}_{\mathrm{h}}+\mathrm{Q}_{\mathrm{k}}$ (Figure $5 b$ ).

a.

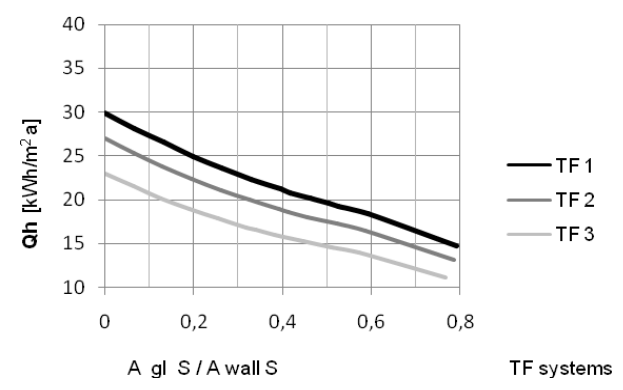

b.

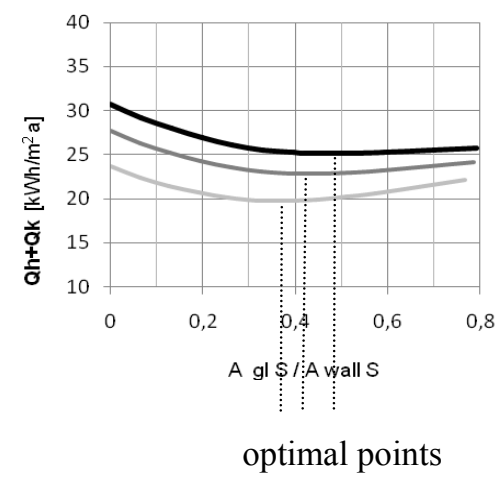

Figure 5: Energy demand: a.) for heating and b.) sum total of energy demand for heating and cooling as a function of AGAW in $\mathrm{TF} 1$ construction system.

The presented results show almost linear functional dependence of $\mathrm{Q}_{\mathrm{h}}$ on the size of the glazing area for all analyzed construction systems. The results for the total energy demand show an interesting appearance related to the optimal point with the lowest $\left(\mathrm{Q}_{\mathrm{h}}+\mathrm{Q}_{\mathrm{k}}\right)$ demand (functional optimum), which is clearly evident in the TF 3 construction system appearing at the range of AGAW $=0.34$ to 0.38 and slightly less evident in the TF 1 system. It is interesting to compare the results with study performed by Inanici and Demirbilek [2] analysed variations of the window-to-wall area ratio from 25 to $90 \%$ for 5 different types of climate in Turkey. It was shown on a brick massive wall for hot climates that an increase of the south facing window area caused an increase of cooling demand and consequently an increase of total energy load, therefore the conventional window-to-wall area ratio of $25 \%$ was optimal for hot climates, what is lower as in our case. Because the $U_{\text {wall-values are essentially different as in our case direct }}$ comparison is not possible, although the analyses for Ankara, which has similar average annual temperature as Ljubljana, showed interesting results, when additional calculation method was used. Also the results for $\mathrm{Q}_{h}$ and $\mathrm{Q}_{\mathrm{k}}$ for different glazing orientations of terraced houses built outside Gothenburg (Sweden) presented in case study research [4] show similarities to our case, with some minimal deviations caused by different climate conditions, but only for a limited range of $\mathrm{AGAW} \approx 0.30$, since the Swedish case study model with a constant glazing area size was oriented in different cardinal directions for the research purposes of the mentioned study.

For comparison purposes as well as for support in setting up the basic principle of the glazing surface's impact on energy behaviour patterns, an 
analysis of the classic old single-panel prefabricated wall elements was carried out. The results for TFcl4 - 6, compared with the results for macro-panel systems, are presented in Figure 6.

According to the data presented in Figure $6 \mathrm{a}$ an expressive linear functional dependence of $\mathrm{Q}_{\mathrm{h}}$ from AGAW for TFCL systems is observed. It is evident that the thermal transmittance of the exterior wall element plays an important role; the higher is the U-value (TFcl) greater and more favourable is the influence of the glazing area increase for the energy demand for heating. From the results presented above we infer that the increase of the south oriented glazing areas in external wall elements of lower insulation features (higher U-value) has greater influence on $\mathrm{Q}_{\mathrm{h}}$ compared to the glazing modifications in wall elements of better insulation features (lower U-value).

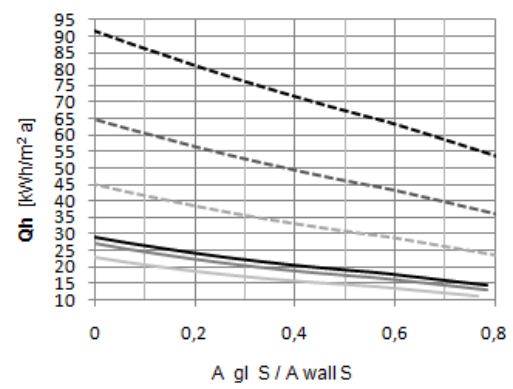

a.)

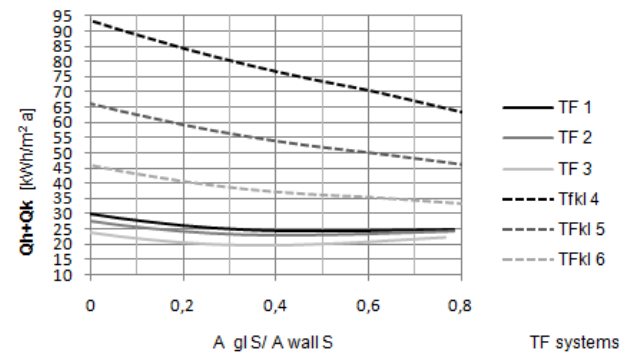

b.)

Figure 6: Comparison of energy demand a.) for heating and b.) sum total of energy demand for heating and cooling as a function of AGAW in TF construction systems.

The analyses of the sum of total heating and cooling demand presented (Figure 6b) seems to be the most interesting; in the case of exterior wall elements with a higher U-value the functional optimum doesn't appear at all, the energy demand behaviour changes from parabolic dependence in construction systems with a low U-value (TF2 and TF3) to almost linear dependence in construction systems with lower insulation features (TFcl 4 - TFcl 6). It is evident that the inclination of a function line presenting TFcl systems depends on the U-value, which is similar to the analysis of the $\mathrm{Q}_{\mathrm{h}}$ demand. Energy savings caused by total glazing area increase (from $\mathrm{AGAW}=0$ to $\mathrm{AGAW} \approx 0.79$ ) are in the range from approximately $31 \mathrm{kWh} / \mathrm{m}^{2}$ a or $33 \%$ of the starting point value for the TFcl 4 system to only $12 \mathrm{kWh} / \mathrm{m}^{2}$ a or $27 \%$ for the TFcl 6 system.

Influence of the glazing type on energy demand is demonstrated on TF 2 wall system with geometrical and material properties from Table 2. The three-layer window glazing (TG) from the already presented study is replaced with the double-layer glazing (DG) with the $U$-value of $U_{g}=1.1 \mathrm{~W} / \mathrm{m}^{2} \mathrm{~K}$. The results for the total annual energy demand for heating and cooling are presented in Figure 7.

It is demonstrated that in case of using the two-layer glazing the optimal point of AGAW with the lowest $\left(\mathrm{Q}_{\mathrm{h}}+\mathrm{Q}_{\mathrm{k}}\right)$ demand is moved on the horizontal axis to 


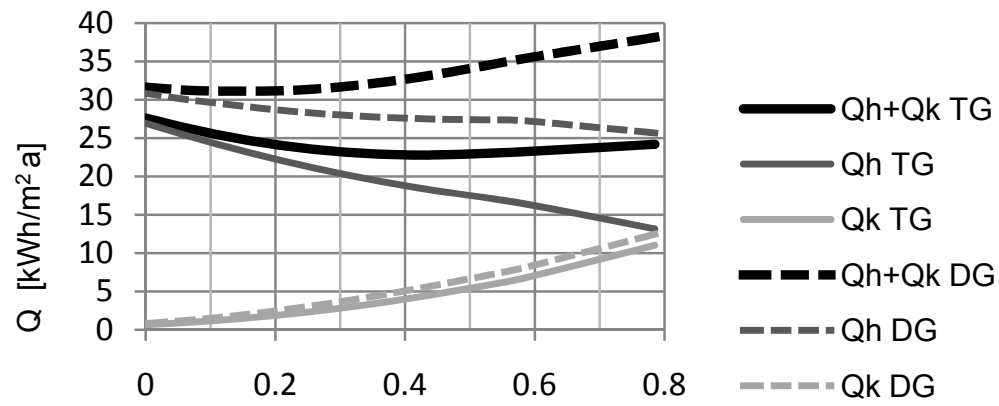

A gl S / A wall S

TF 2

Figure 7: Comparison of energy demand for heating and cooling as a function of AGAW in TF 2 construction system.

the left. The optimum of AGAW appears by the value of AGAW $=0.130$, which is essentially lower as by the three-layer glazing where the optimum appears by $\mathrm{AGAW}=0.413$.

\section{Conclusions}

In current study not only the results for energy demand for heating $\left(\mathrm{Q}_{\mathrm{h}}\right)$, but also the results for the cooling $\left(\mathrm{Q}_{\mathrm{k}}\right)$ energy demand were analysed, while for a prefabricated timber buildings especially in a summer period the overheating presents one of the major problems despite the use of shading devices. It is evident from the results for the sum of the annual energy demand for heating and cooling $\left(\mathrm{Q}_{\mathrm{h}}+\mathrm{Q}_{\mathrm{k}}\right)$ that for the south orientation the optimum or at least the convergence of the function curve is present when installing glazing surfaces in contemporary macro-panel timber-frame wall elements (Figure 5b). The optimal value depends on the thermal transmittance of the wall $\left(\mathrm{U}_{\text {wall-value}}\right)$.

When analysing old classical single-panel wall elements with higher $\mathrm{U}_{\text {wall- }}$ values, the increase of the south oriented glazing surfaces acts positively on total energy load, which is evident in the almost linear dependence of the $\mathrm{Q}_{\mathrm{h}}+\mathrm{Q}_{\mathrm{k}}$ function line according to the AGAW value (Figure 6b). This fact could be useful especially for the renovation principles of the existing timber-framed housing stock built with the classic prefabricated single-panel system, since the installation of large glazing areas in south-oriented external walls improves the energy efficiency of the building.

\section{References}

[1] Johnson R., Sullivan R., Selkowitz S., Nozaki S., Conner C, Arasteh D., Glazing Energy Performance and Design Optimization with Daylighting, Energy and Buildings 6, pp. 305-317, 1984. 
[2] Inanici N. M., Demirbilek F. N., Thermal performance optimization of building aspect ratio and south window size in five cities having different climatic characteristic of Turkey, Building and Environment 35 (1), pp. 41$52,2000$.

[3] Bülow-Hübe H., The Effect of Glazing Type and Size on Annual Heating and Cooling Demand for Swedish Offices, Report No TABK-01/1022. Department of Construction and Architecture, Lund University, Division of Energy and Building Design, Lund, Sweden, 2001.

[4] Persson M.L., Roos A., Wall M., Influence of window size on the energy balance of low energy houses, Energy and Buildings 38, pp. 181-188, 2006.

[5] Bouden C., Influence of glass curtain walls on the building thermal energy consumption under Tunisian climatic conditions: The case of administrative buildings, Renewable Energy 32, p. 141-156, 2007.

[6] Ford B., Schiano-Phan R., Zhongchend D., The Passivhaus Standard in European Warm Climates: Design guidelines for comfortable low energy homes - Part 3: Climate and passive strategies, Passive-on Project report, 2007.

[7] Persson M.L., Windows of Opportunities, The Glazed Area and its Impact on the Energy Balance of Buildings, $\mathrm{PhD}$ Thesis, Uppsala Universitet, 2006.

[8] Rules on the methodology of construction and issuance of building energy certificates, Official Gazette of the Republic of Slovenia, 77/2009, Ministry of the Environment and spatial planning, Republic of Slovenia, 2009.

[9] Rules on efficient use of energy in buildings, (2010), Official Gazette RS, $52 / 2010$

[10] Šijanec Zavrl M. et al., Energetska učinkovitost in energetska izkaznica stavb, Handbook, Ljubljana, 2010.

[11] Praznik M., Kovič S., With active systems and thermal protection to passive and plus energy residential buildings, Proceedings of the International Seminar on Energy Efficiency in Architecture and Civil Engineering, Maribor, 21.10.2010.

[12] European Committe for Standardization, EN 338:2003 E: Structural timber - Strength classes, Brussels, 2003.

[13] Gustavsen A., Jelle B. P., Arasteh D., Kohler K., State-of-the-Art Highly Insulating Window Frames, Research and Market Review, Oslo, 2007.

[14] http://www.geodetska-uprava.si/DHTML_HMZ/wm_ppp.htm

[15] Feist, V., PHPP 2007 Guide book, Passivhaus Institut Dr. Volfgang Feist Darmstadt, 2007.

[16] Žegarac Leskovar V., Premrov M., Impact of the proportion of glazing surface on energy efficiency of prefabricated timber-frame houses. Sustainable Buildings, Design - Operation - Evaluation, Campus Pinkafeld, 11.-12.11.2010. 